\title{
Community-based sanitation as a complementary strategy for the Jakarta Sewerage Development Project: What can we do better?
}

\author{
Rusli Cahyadi ${ }^{*}{ }^{*}$, Dwiyanti Kusumaningrum $^{1}$, Sanusi $^{1}$ \& Ali Yansyah Abdurrahim $^{1}$ \\ ${ }^{1}$ Research Centre for Population, Indonesian Institute of Sciences, Indonesia
}

\begin{abstract}
Indonesian wastewater sector management has been marked as having low coverage and slow in development, even though the system has been initiated since 1969 and the first masterplan for Jakarta Sewerage System and Sanitation Project was developed in 1977. In addition, two other master plans were developed in 1991 and 2012. The long history of planning to develop the citywide sewerage coverage resulted in only marginal coverage. As a complementary and short-term strategy, the Indonesian government also developed community-based sanitation to solve local sanitation problems such as $R W$ Kumuh. In this paper, ideas will be proposed on how to improve the latter strategy and integrate it to the citywide sanitation.
\end{abstract}

\section{Introduction}

The world has become more urbanized, and the human settlements pose its own issues and challenges. In some countries, the result of such rapid urbanization is the failure of the authorities to provide sufficient infrastructure and services to keep up with the increase of population. One of the most pressing issues in most of the cities of the global South is the poor state of sanitation, particularly the provision of wastewater infrastructure and management.

Indonesian wastewater sector management has been marked as low coverage and slow in development [1-8]. The under performance of the sector is attributed to many factors e.g. lack of political support, very low budget allocation (from central and local government) [9], lack of institutional and human resource capacity.

The low coverage of improved sanitation causes about 0.3 million tons of human faeces and two million tons of urine to be released into surrounding water bodies each year in Jakarta [10]. All rivers in Jakarta and most of its ground water are highly contaminated $(75 \%$ and $70 \%$ respectively) [11]. In addition, more than $60 \%$ of wells sampled in a WSP-EAP study in 2004 were contaminated with E. coli, despite most of the wells being classified as protected. Furthermore, in 2006 the Jakarta Environmental Monitoring Agency (BPLHD Jakarta) estimated that $80 \%$ of deep wells were contaminated with E. coli [12].

Various initiative develops by Indonesian government to expand the coverage of improved wastewater management system. Within the Indonesian decentralization, wastewater management is one of mandatory sector of the local government. In addition, sanitation budget is one among other sectors that received significant increase in national budget [13]. Various institutions have been developed to meet the need for better provision and management of wastewater. At national and local level, a Working Group on water and sanitation has been formed (Kelompok Kerja Air Minum dan Penyehatan Lingkungan/Pokja AMPL) to serve as a forum for communication and coordination for better development of water and sanitation [14].

To expand the service and to increase the coverage of better wastewater management, the Jakarta government develop the centralized city scale and community scale sewerage system. However, in Jakarta the development of sanitation infrastructure has been very slow and marked by constant delays. The development of Zona 1 and 6 of Jakarta Sewerage System (JSS) set to be completed in 2020 is nowhere to finish.

To accelerate the improved wastewater management, the DKI Jakarta government is also developing a local off-site system as a complement to the centralized off-site system. As a short-term strategy, the local off-site system is implemented by promoting the community-led total sanitation (CLTS) approach or the community-based sanitation (Sanimas). This approach emphasizes community participation in the planning, development, and maintenance of groupbased communal sanitation systems.

However, the integration of the two systems (i.e. city-scale centralized and community-based systems) has never been a concern of the stakeholders involved. Various community-based sanitation development initiatives operate independently without coordination among one another. The requirements and processes for determining the location of the community-based

\footnotetext{
*Corresponding author: rusli.cahyadi@lipi.go.id/ruslic27@gmail.com
} 
system development also vary. The integration of the two systems is the focus of this paper. Using a variety of available data, this paper demonstrates on how to make the two systems complementary to each other.

\section{Material and methods}

This research uses a qualitative approach in interpreting the sanitation level based on the existing sanitation data and determining the priority of the communal sewerage system area on the kelurahan level. The priorities are determined by integrating data from several existing sanitation data in Jakarta, including the RW Kumuh, Buku Putih Sanitasi, and Naskah Akademis Rencana Perlindungan dan Pengelolaan Lingkungan Hidup. In addition, the priority of the communal sewerage system is also determined based on the geographic location of the Jakarta Sewerage System (JSS) zone.

Each sanitation data determines the sanitation status of each kelurahan. Based on the three sanitation's data, sanitation conditions were compiled into three categories: (1) very poor, (2) poor, (3) less poor. Zones that have been defined are also divided into three categories: (1) Zone 0 as non-priority, (2) Zone 1 and 6 as low priority, and (3) other zones as high priority (table 1).

The list of kelurahan that are included in sanitation programs were then compiled and then combined with the list of kelurahan based on the location on the JSS zone. The kelurahans that are included are considered as areas with poor sanitation condition. However, if the kelurahan is in Zone 0, Zone 1 and Zone 6, the priority level is lowered with the assumption that these areas can use existing sanitation infrastructure (particularly Zone $0)$.

The use of GIS software is important in spatial analysis [15]. Many methods and analyses have been carried out using GIS software. In this research, we use ArcGIS for the analysis. This research method was carried out in several stages: (1) collecting data on the number of sanitation programs based on kelurahan, (2) digitizing the JSS zone based on JICA report, and (3) visualizing priority levels based on analysis using ArcGIS. First, the number of sanitation programs were collected manually based on each program's document. This data was combined with the administrative data using Join and Relate tools in ArcGIS, which combine .xls file into .shp (shapefile) data based on the same attributes. The attribute used in this process is the kelurahan names. Secondly, this combined data needs to be overlaid with the Jakarta Sewerage System (JSS) zone.

The JSS zones used in this paper were digitized from the map available on the JICA report. The digitization of the JSS zones were done using Georeference and Digitize tools in ArcGIS. The digitizing process took quite an effort because it requires accuracy in tracing the existing zone boundaries. After all the digitization processes were done, the combined data will be overlayed with the JSS zones to categorize the sanitation status. The last stage is visualization using symbology that emphasizes cartographic principles. In this paper, graduated colours were used to visualize the sanitation priority levels in DKI Jakarta.

Table 1. State of sanitation, locations, and proposed priority

\begin{tabular}{|l|l|l|}
\hline State of sanitation & Location (Zone) & Priority \\
\hline Very poor & other than $0,1, \& 6$ & High priority \\
\hline Very poor & in zone $1 \& 6$ & Middle priority \\
\hline Very poor & in zone 0 & Low priority \\
\hline Poor & other than $0,1, \& 6$ & Middle priority \\
\hline Poor & in zone $1 \& 6$ & Low priority \\
\hline Poor & in zone 0 & Very low priority \\
\hline Less poor & other than $0,1, \& 6$ & Low priority \\
\hline Less poor & in zone $1 \& 6$ & Very low priority \\
\hline LP & in zone 0 & very low (non) priority \\
\hline
\end{tabular}

Source: authors from RW Kumuh DKI Jakarta [16], Buku Putih Sanitasi DKI Jakarta [17] and Naskah Akademis Rencana Perlindungan dan Pengelolaan Lingkungan Hidup [18]

\section{Result}

\subsection{Management of Wastewater in DKI Jakarta}

Management of wastewater in Jakarta is based on two systems, on-site (i.e. including the use of septic tanks) and off-site systems at the city scale and community scale (see image 2). Further development of the sewerage system is to be directed at the off-site system $^{\dagger}$ because the city's high population density means that the on-site system is increasingly ineffective, especially in preventing groundwater pollution [19].

On-site sanitation is the dominant type of sewerage treatment used by the Jakarta population. A recent study [20] stated that $71 \%$ of the population uses toilets with septic tanks (this figure was $64 \%$ in the 2012) as their means to manage wastewater (mainly in the form of black water, since grey water is typically channelled directly to drainage lines or rivers). Most of the existing septic tanks are insufficient, do not meet relevant technical requirements or lack regular desludging and maintenance [21, 22]. Effective sewage management can be accessed by only 3-4\% of Jakarta's population within the covering of the existing centralized piping system; and there is no data available on the number of communal sewerage systems (community scale sewerage). However, the Jakarta government stated that $86 \%$ of the population access to toilet while $14 \%$ (equal to 470 thousand households) still practice open defecation [23].

Access to proper domestic wastewater management according to PD PALJaya is only $16.96 \%$ (13.52\% offsite/centralized system and $3.44 \%$ on-site system) of Jakarta's population. Thus, $86 \%$ of the city population wastewater is not treated properly [24]. The low

${ }^{\dagger}$ Governor Regulation number 41/2016. 
coverage of the better/proper wastewater treatment explains various environmental problems stated in the introduction.

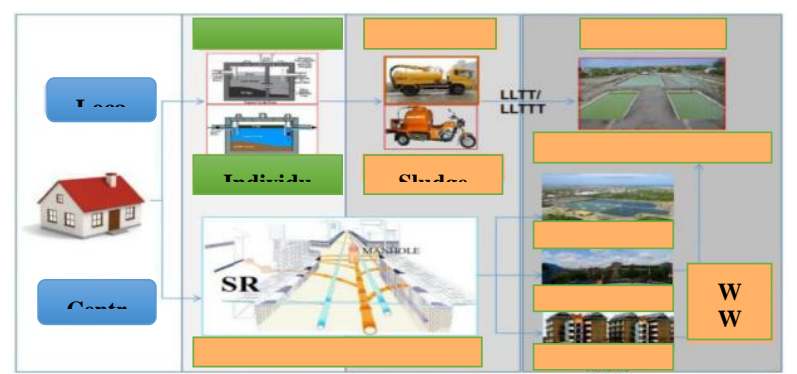

Pig. 1. Wastewater management system

In addition to the low coverage of the sewer network, the existing Jakarta sewerage system also has idle capacity of the wastewater treatment plant (WWTP) which is at odds considering the long history of efforts to develop the system. Since 1969 the Jakarta city government has initiated efforts to improve the general state of sanitation, when the well-cited and worldwide replicated Muhammad Husni Thamrin program (Program MHT) or Kampung Improvement Program (KIP) was launched [25-27]. In addition, the existing centralized system have been developed since 1983 and operated in 1983 under Badan Pengelola Air Limbah/BPAL which then transformed as Perusahaan Daerah Pengelolaan Air Limbah/PD PAL in 1991 [28].

The Jakarta sewerage system (JSS) is currently developed by the Indonesian government by means of a centralized domestic wastewater management system (SPALD-T) on city and residential scale which include the construction of a Wastewater Treatment Plant (IPAL) and a piping network. Within this initiative, the province area has 15 zones of development (14 new zones and 1 existing zone/zone 0 ).

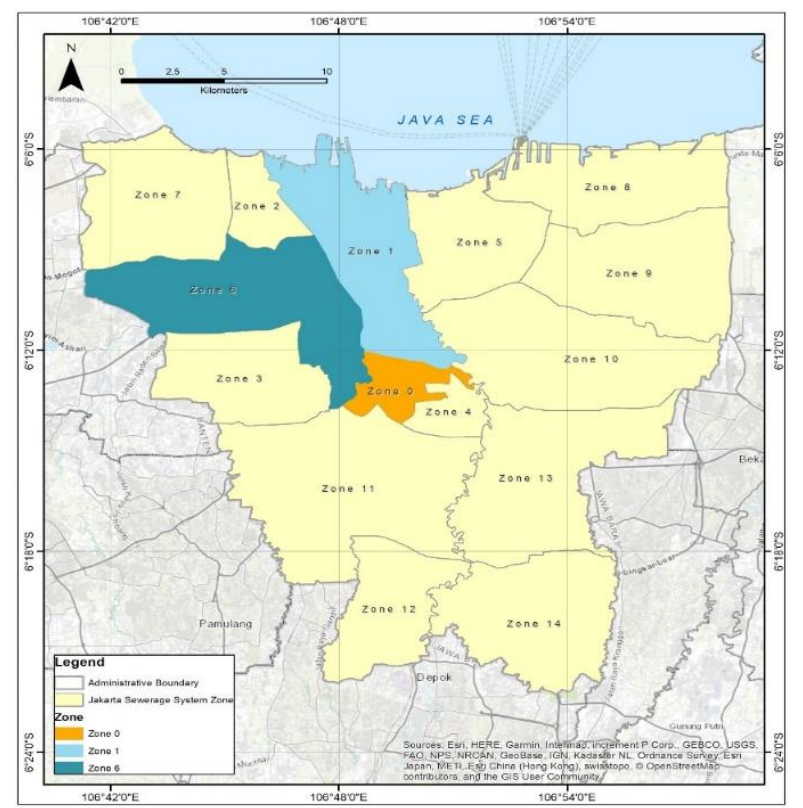

Pig 2. Map Existing and future development of Jakarta Sewerage System.
Furthermore, the government divided the zones into three different plans, i.e. short, medium, and long terms plans. The plans are set to be completed in 2020, 2030, and 2050, respectively. The development of each plan is projected to increase the coverage of Jakarta's wastewater services from the current state of $4 \%$ to $20 \%$. Once the whole zone operates in 2050 the service coverage is expected to reach $90 \%$.

In line with the development of a centralized system, the government has also developed the communal off-site system as a complementary and considered as short-term strategy. The problem that has arisen is the slow pace of the centralized piping system, so it is important to encourage the local system. However, the integration of local systems into a centralized system does not appear to have received attention.

Table 2. Jakarta Sewerage System (JSS) development priority and target year of development

\begin{tabular}{|c|c|c|}
\hline Priority & Zone & $\begin{array}{l}\text { Target (Year of } \\
\text { Development) }\end{array}$ \\
\hline 1 & 1 & \multirow{2}{*}{$\begin{array}{l}\text { Short-term plan } \\
(2012-2020)\end{array}$} \\
\hline 2 & 6 & \\
\hline 3 & 10 & \multirow{4}{*}{$\begin{array}{l}\text { Mid-term plan } \\
(2021-2030)\end{array}$} \\
\hline 4 & 5 & \\
\hline 5 & 8 & \\
\hline 6 & 4 & \\
\hline 7 & 9 & \multirow{7}{*}{$\begin{array}{l}\text { Long-term plan } \\
(2030-2050)\end{array}$} \\
\hline 8 & 7 & \\
\hline 9 & 11 & \\
\hline 10 & 14 & \\
\hline 11 & 3 & \\
\hline 12 & 13 & \\
\hline 13 & 2 & \\
\hline
\end{tabular}

In line with the development of a centralized system, the government has also developed the communal offsite system as a complementary and considered as shortterm strategy. The problem that has arisen is the slow pace of the centralized piping system, so it is important to encourage the local system. However, the integration of local systems into a centralized system does not appear to have received attention.

Within the urban context, the Indonesian government developed the Community-based Sanitation Program (sanitasi berbasis masyarakat also known as Sanimas). Now, there are at least four projects under Sanimas developed by the Indonesian Government, i.e. Sanimas Regular, Sanimas DAK SLBM, Sanimas USRI, Sanimas IDB. In addition, there are also initiatives conducted by NGO and business entities as part of corporate social responsibility.

However, it is suggested that the two strategies do not complement each other, in addition to lack of fair mechanism in the selection of location for the community-based sanitation program. A concerted effort to develop both systems are in need if the development of wastewater management for all people is at stake.

The results showed that the level of sanitation based on the existing programs in various kelurahan in Jakarta 
varied widely. Based on the table below, West Jakarta is the area with the most very poor sanitation level (28 kelurahan) followed by North Jakarta (24 kelurahan). Meanwhile, Central Jakarta, South Jakarta and East Jakarta have 18, 14, 13 of kelurahan in very bad sanitation levels respectively. Geographically, the proportion of kelurahans with the very poor sanitation are highest in the North Jakarta followed by West, Central, East and South Jakarta. $77 \%$ of total areas of the North Jakarta having very poor sanitation levels. In addition, West Jakarta also has the same pattern with half of the region having a very poor sanitation level $(50 \%)$.

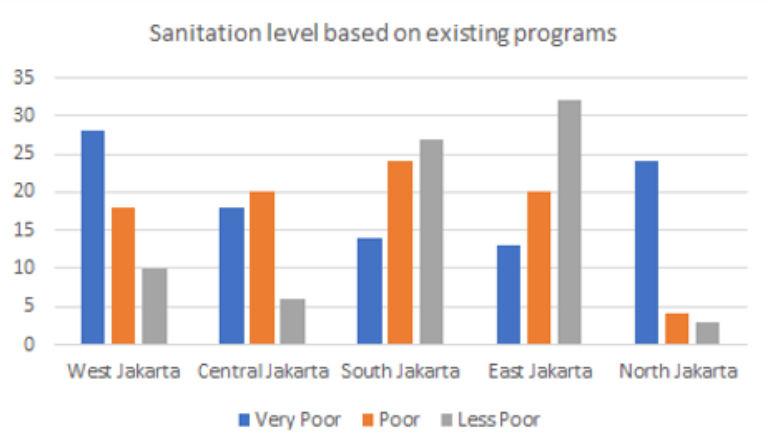

Pig 3. State of sanitation based on various existing programs

However, after classifying the sanitation level based on existing programs, the community-based sewerage systems' priority level was then defined by these sanitation levels overlayed with the JSS zone. The area which has a very poor sanitation level and are not within the Zone 1 or 6 will be put on the highest priority. This also applies to the next classification, areas with a poor sanitation level will be put on the second priority (middle priority), and so on.

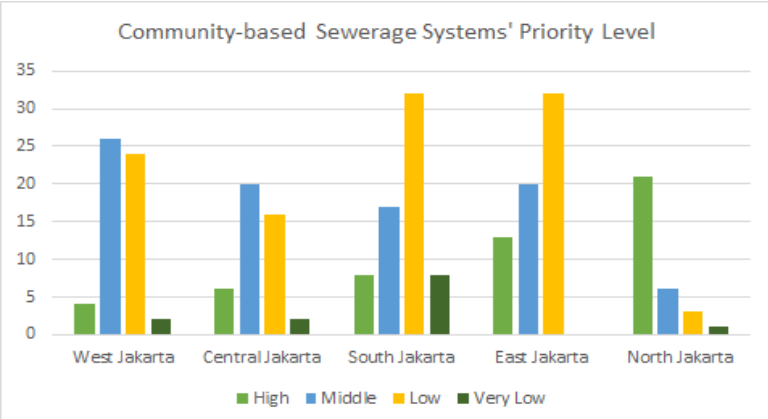

Pig.4. Community-based sewerage system' priority level

The results show that North Jakarta is an area that should be prioritized for the development of community-based sewerage systems. Nearly half of the total high priority is in North Jakarta (21 out of 52 kelurahan). On the other hand, despite having the poorest sanitation conditions, West Jakarta only has 4 kelurahan with high priority status. This is due to the large number of kelurahan in Zone 1 which are assumed to be facilitated by the Jakarta sewerage system. Even so, West Jakarta has the most kelurahan with middle priority status among other cities (26 kelurahan), followed by East Jakarta (20 kelurahan). Central Jakarta
(20 kelurahan), South Jakarta (17 kelurahan), and North Jakarta (6 kelurahan).

$19.9 \%$ of areas in Jakarta, or 52 kelurahan, are areas with high priority status. These high priority areas are scattered in the northern part of Jakarta, followed by some areas in South Jakarta and East Jakarta (see Map). This distribution can assist policy makers in determining priority areas that should be considered in communitybased management development. The community-based sewerage system must be integrated with an established information system, so that the project locations are based on the priorities set or proposed by this paper.

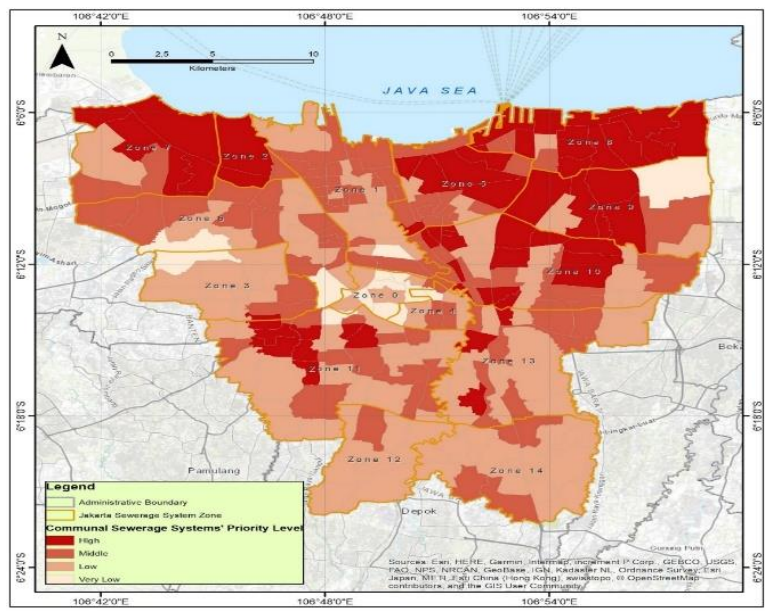

Pig 5. Distribution of kelurahans' priority

\section{Discussion}

\subsection{Integrating centralized and community- based sewerage systems}

The idea of distributive justice is related to "the morally proper distribution of benefits and burdens among society's members" [29]. Meaning that, the distribution of urban infrastructure should follow certain accepted criteria. The most used criteria of social justice within urban development is the value of Need. As exemplified by the case of the Sanimas project distribution, the DKI Jakarta government develop priority to allocate the project based on value of Need [30]. Kelurahan with poor state of sanitation, therefore, are prioritized in receiving the project. However, the application of the Need value simply ignores the existence of the Jakarta Sewerage System plan that places kelurahan in an unequal position in relation to the development of sanitation.

Poor state of sanitation are conditions that equally distributed in DKI Jakarta area. However, an area with poor sanitation and geographically situated in the shortterm plan of JSS have bigger benefit compared to area with same state of sanitation but situated in the long- and mid-term plan of JSS. The community who reside in Zone 0 have the chance to connect their domestic wastewater to the developed centralized system in addition to the community-based sewerage system. The same benefit also applied for those who live in the Zone 1 and 6 . With the current development of the centralized 
piping system, the community will also have two benefits at the same time. However, the same benefits are not shared by the community who live in the midand long-term plan of JSS. For the mid-term planned area they have to wait up to 10 years (2030) to have the same level of benefit and roughly 30 years for those in the long-term development areas. To justly distribute the "benefits and burdens" or "conditions and goods" [31] the idea of integrating the distribution of communitybased sewerage with the development of centralized is proposed.

The importance of the proposed idea is related to the fact that the number of Community-based Sanitation (Sanimas) programs are limited. Therefore, a just mechanism in the distribution of the project are necessary. Literatures suggest that the uneven distribution of public services have led to the development of socio-spatial inequality [32-35] echoing the need for a more just distribution of urban resources.

The proposed idea is based on principle of Equality in the allocation of urban infrastructure. While the principle of Need is used to develop the priority (very poor, poor, and less poor kelurahan), the value of Equality concerns with existence or non-existence of certain advantage in one area compared to other. The development of Jakarta Sewerage System in three phases, leave the communities and areas in the the midand long-term are not in equal position. Therefore, the development of Sanimas IDB should be prioritize in these areas.

\section{Discussion}

Sanitation development in Jakarta is very slow, which resulted in the number of areas (kelurahan) that having sanitation problems are evenly distributed in the city. The plan to develop a wastewater management system in Jakarta is primarily directed at the development of a centralized piping system (JSS). However, since the system requires massive funds, the government divides its development into three stages with three development zones. As an intermediate strategy, the Jakarta government is also developing a community-based wastewater management system (the Sanimas). The communal system was mainly developed in poor slum areas. A Need-based priority system was then developed by the government, where areas with very bad, bad, and less bad sanitation conditions respectively became a priority.

This article proposed a robust way to identify Need by integrating different Need-based identification of the state of sanitation at kelurahan level. Furthermore, the article also proposed the inclusion of principle of equality to develop an even more just mechanism in the allocation of resource. The three stages development of JSS has resulted in uneven distribution of "benefit and burden" in relation to the allocation of Sanimas program. Poor state sanitation areas within the already developed Zone 0 and the short-term development plan (Zone $1 \&$ 6) have the chance to connect their domestic wastewater to the system, in addition to the chance of allocated community-based sewerage system
(Sanimas). The benefits that are not shared by areas and communities who reside in the mid- and long-term development plan areas.

The proposed idea of integrating the JSS with the community-based sewerage system development is based on the application of principle of Need and Equality within the literature of urban resources allocation. The principle of Need operates by identifying the area or community with the most Need or and then prioritize them in the allocation of urban resource. The principle of equality is added to make sure that certain benefits or burdens that entails an area or community is considered in developing the priority.

\section{References}

1. Cameron, L., Olivia, S., \& Shah, M. Scaling up sanitation: evidence from an RCT in Indonesia. Journal of Development Economics 138, 1-16 (2019)

2. Komarulzaman, A., Smits, J., \& de Jong, E., Clean water, sanitation and diarrhoea in Indonesia: Effects of household and community factors. Global public health, 12(9), 1141-1155 (2017)

3. Patunru, A. A., Access to Safe Drinking Water and Sanitation in Indonesia. Asia \& the Pacific Policy Studies, 2(2), 234-244 (2015)

4. UTS-ISF. (n.d.). Indonesia WASH Sector Brief, Retrieved from

5. Water and Sanitation Program, Improving On-site Sanitation and Connections to Sewers in Southeast Asia Insights from Indonesia and Vietnam, Retrieved from (2015a)

6. Water and Sanitation Program, Water Supply and Sanitation in Indonesia: Turning Finance into Service for the Future, Retrieved from (2015b)

7. World Bank, East Asia Pacific Region Urban Sanitation Review: Indonesia Country Study. In: World Bank Washington, DC (2013)

8. World Bank, \& AusAID, Urban sanitation review: Indonesia Country Study, Retrieved from (2013)

9. UNICEF, Equity in Public Financing of Water, Sanitation and Hygiene (WASH) INDONESIA, Retrieved from (2016a)

10. Water and Sanitation Program East Asia and the Pacific, \& World Bank Office Jakarta, Economic Impacts of Sanitation in Indonesia: A five-country study conducted in Cambodia, Indonesia, Lao PDR, the Philippines, and Vietnam under the Economics of Sanitation Initiative (ESI), Retrieved from (2008)

11. Asian Development Bank, Urban wastewater management in Indonesia: Key Principles and Issues in Drafting Local Regulations (2017)

12. Water and Sanitation Program East Asia and the Pacific, \& World Bank Office Jakarta, Economic Impacts of Sanitation in Indonesia: A five-country study conducted in Cambodia, Indonesia, Lao PDR, the Philippines, and Vietnam under the 
Economics of Sanitation Initiative (ESI), Retrieved from (2008)

13. Unicef, Equity in public financing of water, sanitation and hygiene (WASH) Indonesia. no. June, 52 (2016b)

14. KPN/Bappenas (2013)

15. Flowerdew, R. and Martin, D., Methods in Human Geography: a guide for students doing a research project. Second edi. Essex: Pearson Education Limited (2005)

16. RW Kumuh DKI Jakarta (2013)

17. Buku Putih Sanitasi DKI Jakarta (2012)

18. Naskah Akademis Rencana Perlindungan dan Pengelolaan Lingkungan Hidup (2015)

19. Dsikowitzky, L., Schäfer, L., Dwiyitno, Ariyani, F., Irianto, H. E., \& Schwarzbauer, J., Evidence of massive river pollution in the tropical megacity Jakarta as indicated by faecal steroid occurrence and the seasonal flushing out into the coastal ecosystem. Environmental Chemistry Letters, 15(4), 703-708. doi:10.1007/s10311-017-0641-3 (2017)

20. Zahra, S. A., Analysis on the management of waste domestic system in populous neighborhoods, Paper presented at the E3S Web of Conferences (2018)

21. Gazali, H., Riani, E., \& Kurniawan, B., Regular desludging: Reconnect a missing chain in on-site system of Depok city (2006)

22. Mills, F., Blackett, I. C., \& Tayler, K., Assessing on-site systems and sludge accumulation rates to understand pit emptying in Indonesia (2014)

23. Pemerintah Provinsi DKI Jakarta, Desain besar penyediaan layanan air minum dan air limbah domestik Provinsi DKI Jakarta 2018-2022, Retrieved from (2017)

24. Pemerintah Provinsi DKI Jakarta. (n.d.). Potensi investasi sektor air limbah, Retrieved from http://ptsp.jakarta.go.id/penanaman_modal/files/se ktor-investasi/Potensi-Investasi-Sektor-AirLimbah.pdf

25. Ernawati, R., Santosa, H. R., \& Setijanti, P., Facing urban vulnerability through kampung development, case study of kampungs in Surabaya, Indonesia. development, 14, 15 (2013)

26. Funo, S., Yamamoto, N., \& Silas, J, Typology of kampung houses and their transformation process. Journal of Asian architecture and building engineering, 1(2), 193-200 (2002)

27. Tunas, D., \& Darmoyono, L. T., Self-help housing in Indonesia. In Affordable housing in the urban Global South: seeking sustainable solutions (pp. 166-180): Routledge (2014)

28. PD PAL Jaya, Sejarah singkat, Retrieved from https://www.paljaya.com/profil/sejarah-singkat (2016)

29. Young, Justice and the Politics of Difference: Princeton University Press (1990)
30. Cahyadi, Rusli, Social justice and planning policy: The provision of sewerage infrastructure in Jakarta, Indonesia. PhD thesis. School of Earth and Environmental Sciences, The University of Queensland, Australia. Available at https://espace.library.uq.edu.au/view/UQ:9e58691 (2019)

31. Deutsch, M, Equity, equality, and need: What determines which value will be used as the basis of distributive justice?. Journal of Social issues, 31(3), 137-149 (1975)

32. Graham, S., \& Marvin, S., Splintering urbanism: networked infrastructures, technological mobilities and the urban condition: Psychology Press (2001)

33. Kooy, M., \& Bakker, K., Splintered networks: The colonial and contemporary waters of Jakarta. Geoforum, 39(6), 1843-1858. doi:10.1016/j.geoforum.2008.07.012 (2008)

34. McFarlane, C. Infrastructure, interruption, and inequality: Urban life in the global South. Disrupted cities: When infrastructure fails, 131$144(2010)$

35. Van Eijk, G., Unequal networks: Spatial segregation, relationships and inequality in the city (Vol. 32): Gwen van Eijk (2010) 